\title{
STUDI MANAJEMAN RISIKO PADA BANK SYARIAH INDONESIA (BSI)
}

\section{Oleh:}

\author{
Ahmad Suhaimi, M.A \\ Tenaga Ahli Anggota DPR RI \\ Email: hemi.latanza@gmail.com
}

\begin{abstract}
ABTSRAK
Risiko dalam konteks perbankan merupakan suatu kejadian potensial, baik yang dapat di perkirakan maupun yang tidak dapat diperkirakan dan berdampak negatif terhadap pendapatan dan permodalan bank. Risiko-risiko tersebut tidak dapat dihindari, tetapi dapat dikelola dan dikendalikan. Oleh karena itu sebagaimana lembaga perbankan pada umumnya. Dalam menghadapi potensi risiko, maka Bank Syariah Indonesia (BSI) harus menerapkan manajemen risiko yang tepat.

Penerapan manajemen risiko pada Bank Syariah Indonesi setidaknya memuat: Penerapan manajemen risiko secara umum; Penerapan manajemen risiko untuk masing-masing risiko, mencakup 8 risiko, yaitu risiko kredit, risiko pasar, risiko likuiditas, risiko operasional, risiko hukum, risiko strategis, risiko kepatuhan, dan risiko reputasi. Penilaian profil risiko. Kualitas penerapan manajemen risiko meliputi:Tata kelola risiko Kerangka manajemen risiko Kecukupan proses manajemen risiko dan Sistem pengendalian internal yang menyeluruh.
\end{abstract}

\section{PENDAHULUAN}

Perbankan Islam atau perbankan syariah, merupakan fenomena baru dalam dunia ekonomi modern, kemunculannya seiring dengan upaya gencar yang dilakukan oleh para-pakar Islam dalam meningkatkan kesejahteraan umat melalui sistem ekonomi Islam yang diyakini akan mampu mengganti dan memperbaiki sistem ekonomi konvensional yang berbasis pada bunga. Karena itulah sistem perbankan syariah menerapkan sistem bebas bunga (interest free) dalam operasionalnya, dan karena itu rumusan yang paling lazim untuk mendefinisikan perbankan syariah adalah bank yang beroperasi sesuai dengan prinsip-prinsip syariat Islam, dengan mengacu kepada Al-Quran dan AlSunnah sebagai landasan dasar hukum dan operasional.

Bank syariah pada awalnya dikembangkan dari respon kelompok ekonom dan praktisi perbankan muslim yang berupaya mengakomodasi desakan dari berbagai pihak yang menginginkan agar tersedia jasa transaksi keuangan yang dilaksanakan sejalan dengan nilai moral dan prinsip syariah Islam. Pada perjalanannya sistem perbankan berbasis syariah, semakin hari semakin populer bukan hanya di negara-negara Islam tetapi juga negara-negara Barat, yang ditandai dengan makin suburnya bank-bank yang menerapkan konsep syariah (Suryani, 20I2:III-I3I)

Dalam konteks Indonesia, perkembangannya Bank Syariah telah sampai pada pembentukan PT Bank Syariah Indonesia Tbk (BSI) yang resmi beroperasi pada I Februari 202I. BSI merupakan bank syariah terbesar di Indonesia hasil penggabungan (merger) tiga bank syariah dari Himpunan Bank Milik Negara (Himbara), yaitu: PT Bank 
BRI Syariah (BRIS), PT Bank Syariah Mandiri (BSM), dan PT Bank BNI Syariah (BNIS). Terobosan kebijakan pemerintah untuk melakukan merger tiga bank syariah ini diharapkan dapat memberikan pilihan lembaga keuangan baru bagi masyarakat sekaligus mampu mendorong perekonomian nasional.

Sebelumnya, Kementerian Badan Usaha Milik Negara (BUMN) pada tanggal 12 Oktober 2020 mengumumkan secara resmi bahwa telah dimulai proses merger tiga bank umum syariah anak usaha bank BUMN dan ditargetkan selesai pada bulan Februari 2021. Beberapa pertimbangan yang mendorong proses merger disampaikan Menteri BUMN Erick Thohir, antara lain pemerintah melihat bahwa penetrasi perbankan syariah di Indonesia sangat jauh ketinggalan dibandingkan dengan bank konvensional. Di samping itu, pemerintah melihat peluang bahwa merger ini bisa membuktikan sebagai negara dengan mayoritas muslim punya bank syariah kuat secara fundamental. Bahkan, Presiden Joko Widodo mempertegas lagi bahwa pembentukan bank syariah merupakan salah satu upaya pemerintah untuk memperkuat industri keuangan syariah di Indonesia (cnbcindonesia.com, 26 Januari 202I).

Salah satu visi yang diemban BSI adalah menjadi bank syariah berskala dunia, yaitu target untuk masuk dalam peringkat 10 besar bank syariah dunia dengan nilai kapitalisasi besar pada 2025. Pencapaian target tersebut menjadi tantangan yang besar karena Otoritas Jasa Keuangan (OJK) mencatat total aset perbankan syariah, mencakup bank umum syariah (BUS) dan unit usaha syariah (UUS) per November 2020 hanya 3,97\% dari total aset bank umum. Selain itu, nilai pembiayaan Syariah BUS dan UUS baru $2,49 \%$ dari total pembiayaan bank umum. Tingkat inklusi keuangan syariah pada 2019 pun turun 200 bps dari semula II, I\% pada 2016 menjadi tinggal 9, I0\%. Sebaliknya, tingkat inklusi keuangan perbankan konvensional justru meningkat dari $65,6 \%$ pada 2016 menjadi $75,28 \%$ pada 2019 (Bisnis Indonesia, 2 Februari 202I).

Persoalannya, kedepannya keberadaan Bank syariah Indonesia akan selalu berhadapan dengan berbagai jenis risiko dengan kompleksitas beragam dan melekat pada kegiatan usahanya. Risiko dalam konteks perbankan merupakan suatu kejadian potensial, baik dapat diperkirakan (anticipated) maupun yang tidak dapat diperkirakan (unanticipated) yang berdampak negatif terhadap pendapatan dan permodalan bank (Karim, 20 I 3: 255).

Situasi eksternal dan internal perbankan mengalami perkembangan pesat yang diikuti dengan semakin kompleksnya risiko kegiatan usaha perbankan sehingga diperlukan penerapan manajemen risiko yang matang.
Penerapan manajemen risiko akan memberikan manfaat baik kepada perbankan maupun otoritas pengawasan perbankan. Manajemen risiko dibutuhkan untuk mengidentifikasi, mengukur, dan mengendalikan berbagai macam risiko (Veitzal dan Arifin, 2010:94I).

Adanya krisis finansial dunia yang terjadi mulai 2008, dan berlanjut hingga saat ini, semakin menegaskan perlunya penerapan manajemen risiko secara konsisten. Dibandingkan dengan krisis finansial 1998, dalam menghadapi krisis tahun 2008 perbankan Indonesia sudah lebih siap (Ikatan Bankir Indonesia, 2014: 339). Mekanisme yang terdapat pada BSI, tidak dapat terlepas pada risiko dalam menjalankan roda usahanya (Saputra, 2012: 2). Dari itu, BSI harus dapat mengidentifikasi setiap risiko yang sedang dihadapi Romdhoni, 20I2).

Adapun tujuan penelitian ini untuk mengetahui seberapa besar risiko yang dihadapi Bank Syaria Indonesia dan bagaimana cara mengendalikannya.

\section{LANDASAN TEORI}

\section{Manajemen Risiko Pada Perbankan Syariah}

Manajemen risiko adalah suatu sistem pengawasan risiko dan perlindungan harta benda, hak milik dan keuntungan badan usaha atau peroranganatas kemungkinan timbulnya kerugian karena adanya suatu risiko. Menurut Irham Fahmi (20I0: 2) Manajemen Risiko adalah "suatu bidang ilmu yang membahas tentang bagaimana suatu organisasi menerapkan ukuran dalam memetakan berbagai permasalahan yang ada dengan menempatkan berbagai pendekatan manajemen secara komperhensif dan sistematis."

Manajemen risiko didefinisikan sebagai suatu metode logis dan sitematik dalam identifikasi, kuantifikasi, menentukan sikap, menetapkan solusi, serta melakukan monitor dan pelaporan risiko yang berlangsung pada setiap aktivitas atau proses. Menurut kamus besar bahasa risiko adalah "akibat yang kurang menyenangkan (merugikan, membahayakan) dari suatu perbuatan atau tindakan." Dengan kata lain, risiko merupakan potensi kerugian akibat terjadinya suatu peristiwa tertentu. Risiko dalam konteks perbankan merupakan suatu kejadian potensial, baik yang dapat diperkirakan (expected) maupun yang tidak dapat diperkirakan (unexpected) yang berdampak negatif terhadap pendapatan dan permodalan bank. Risiko juga dapat dianggap sebagai kendala dalam pencapaian suatu tujuan (Surat Edaran Bank Indonesia No. I 3 tahun 20 I I).

Potensi risiko ini juga akan dialami oleh BSI, mengingat Masa depan industri perbankan Syari'ah akan sangat bergantung pada kemampuannya untuk merespons 
perubahan dalam dunia keuangan. Fenomena globalisasi dan revolusi teknologi informasi, menjadikan ruang lingkup perbankan Syari'ah sebagai lembaga keuangan telah melampaui batas perundang-undangan suatu negara. Implikasinya adalah, sektor keuanganpun menjadi semakin dinamis, kompetitif dan kompleks. Terlebih lagi adanya tren pertumbuhan merger lintas segmen, akuisisi, dan konsolidasi keuangan, yang membaurkan risiko unik tiap segmen dari industri keuangan tersebut (Rahmani, 2009: I5I- 165).

Dalam rangka meminimalisasi risiko yang dapat menimbulkan kerugian bagi bank, maka bank harus menerapkan manajemen risiko, yaitu serangkaian prosedur dan metodologi yang digunakan untuk mengidentifikasi, mengukur, memantau, dan mengendalikan risiko yang timbul dari kegiatan usaha bank (Arifin, 2009: 272).Adapun tujuan manajemen risiko adalah: (I) Menyediakan informasi tentang risiko kepada pihak regulator; (2) Memastikan bank tidak mengalami kerugian yang bersifat unacceptable; (3) Meminimalisasi kerugian dari berbagai risiko yang bersifat uncontrolled; (4) Mengukur eksposur dan pemusatan risiko; (5) Mengalokasikan modal dan membatasi risiko (Karim, 20I3: 255).

Keberadaan manajemen risiko sebagai aktivitas yang utama dari suatu bank sebagai lembaga intermediasi yang bertujuan untuk mengoptimalkan trade off antara risiko dan pendapatan, serta membantu merencanakan dan pembiayaan pengembangan usaha secara tepat, efektif dan efisien. Setiap lembaga keuangan, termasuk bank harus dapat mengidentifikasi dan mengontrol risiko yang melekat dalam kegiatan pengelolaan dana simpanan, portofolio aktiva produktif, dan kontrak off balance sheet (Veitzal dan Arifin, 2010: 943). Pada perbankan syariah, sistem manajemen risiko di bank-bank meliputi beberapa tahap berturut-turut sebagai berikut: (I) Identifikasi risiko, (2) Risiko dan kuantifikasi modal, (3) Mengumpulkan atau pengelompokan risiko yang sama, (4) Kontrol sebelumnya, dan (5) Pemantauan risiko (Emira, 20।3: 180-193).

Bank Indonesia mengungkapkan, bahwa Kebijakan dalam Manajemen Risiko terdapat dalam hal berikut ini: (I) Penetapan Risiko yang terkait dengan produk dan transaksi perbankan; (2) Penetapan penggunaan metode pengukuran dan sistem informasi Manajemen Risiko; (3) Penentuan limit dan penetapan toleransi Risiko; (4) Penetapan penilaian peringkat Risiko; (5) Penyusunan rencana darurat (contingency plan) dalam kondisi terburuk; (6) Penetapan sistem pengendalian intern dalam penerapan manajemen risiko (Surat Edaran No. I 3 Tahun 20 I I).

Sasaran kebijakan manajemen risiko adalah mengidentifikasi, mengukur, memantau, dan mengendalikan jalannya kegiatan usaha bank dengan tingkat risiko yang wajar secara terarah, terintegrasi, dan berkesinambungan. Dengan demikian, manajemen risiko berfungsi sebagai filter atau pemberi peringatan dini (early warning system) terhadap kegiatan usaha bank (Karim, 20 I 3: 255).

Meskipun unsur pokok dari manajemen risiko meliputi identifikasi, mengukur, memonitor, dan mengelola berbagai eksposur risiko. Namun, semua hal tersebut tidak akan dapat diimplementasikan tanpa disertai dengan proses dan sistem yang jelas. Keseluruhan proses manajemen risiko harus meliputi seluruh departemen atau divisi kerja dalam lembaga sehingga tercipta budaya manajemen risiko (Khan and Ahmed, 200I: 30).

Mengingat perbedaan kondisi pasar, struktur, ukuran, serta kompleksitas usaha bank, maka tidak ada satu sistem manajemen risiko yang universal untuk seluruh bank. Dengan demikian, setiap bank harus membangun sistem manajemen risiko sesuai dengan fungsi dan kompleksitas bank, dan menyediakan sistem organisasi manajemen risiko pada bank sesuai dengan kebutuhan Agar mencapai petumbuhan bisnis yang berkelanjutan (sustainable business growth)(lkatan Bankir Indonesia: 342).

\section{METODE PENELITIAN}

Penelitian ini merupakan penelitian studi literatur dengan tujuan untuk mendeskripsikan tentang masalah yang diteliti. Teknik pengumpulan data dengan studi kepustakaan yang berasal dari berbagai sumber seperti buku, internet serta jurnal penelitian yang memiliki kesaman topik dengan yang peneliti bahas.

Penelitian kepustakaan atau kajian literatur (literature review, literature research) merupakan penelitian yang mengkaji atau meninjau secara kritis pengetahuan, gagasan, atau temuan yang terdapat di dalam tubuh literatur berorientasi akademik (academic-oriented literature), serta merumuskan kontribusi teoritis dan metodologisnya untuk topik tertentu. Adapun sifat dari penelitian ini adalah analisis deskriptif, yakni penguraian secara teratur data yang telah diperoleh, kemudian diberikan pemahaman dan penjelasan agar dapat dipahami dengan baik oleh pembaca.

\section{HASIL DAN PEMBAHASAN}

\section{I Karakteristik Manajemen Risiko BSI}

BSI merupakan unit bisnis yang secara langsung akan menghadapi risiko manajemen bank itu sendiri. Bahkan, apabila dicermati secara mendalam, bahkan Muhammad (201 I: 357) mengatakan keberadaan bank syariah sangat 
rentan akan risiko. Secara umum, risiko yang dihadapi perbankan BSI merupakan risiko yang relatif sama dengan yang dihadapi bank konvensional. Namun, perbankan syariah memiliki keunikan tersendiri dalam menghadapi risiko karena harus mengikuti prinsip-prinsip syariah (Umam, 2013: 134).

Manajemen risiko pada perbankan syariah mempunyai karakter yang berbeda dengan bank konvensional, terutama karena adanya jenis-jenis risiko yang khas melekat hanya pada bank-bank yang beroperasi secara syariah. Dengan kata lain, perbedaan mendasar antara bank Islam dan bank konvensional bukan terletak bagaimana cara mengukur, melainkan pada apa yang dinilai. (Karim, 20I3: 256).

Perbedaan tersebut akan tampak terlihat dalam proses manajemen risiko operasional BIS, diantaranya;

I. Identifikasi Risiko

Identifikasi risiko dilakukan dalam BSI tidak hanya mencakup berbagai risiko yang ada pada bank-bank secara umum. Melainkan meliputi berbagai risiko yang khas hanya pada bank-bank yang beroperasi berdasarkan prinsip syariah. Dalam hal ini, keunikan tersebut terbagi menjadi 6 (enam) hal yakni, proses transaksi pembiayaan, proses manajemen, sumber daya manusia, teknologi, lingkungan eksternal, dan kerusakan (Karim, 20।3: 257).

2. Penilaian Risiko

Dalam penilaian risiko, keunikan perbankan syariah terlihat pada hubungan antara probability dan impact, atau biasa dikenal sebagai qualitative approach.

3. Antisipasi Risiko

Tujuan antisipasi risiko dalam BSI, meliputi; Pertama, sebagai upaya preventive. Dalam hal ini, BSI memerlukan persetujuan DPS untuk mencegah kekeliruan proses dan transaksi dari aspek syariah. Disamping itu, BSI juga memerlukan opini bahkan fatwa DSN bila Bank Indonesia memandang persetujuan DPS belum memadai atau berada di luar kewenangannya. Kedua, Diperlukan detective. Pengawasan dalam BSI meliputi dua aspek, yaitu aspek perbankan oleh Bank Indonesia dan aspek syariah oleh DPS. Kadangkala timbul pemahaman yang berbeda atas suatu transaksi apakah melanggar syariah atau tidak. Ketiga, Recovery Koreksi atas suatu kesalahan dapat melibatkan Bank Indonesia untuk aspek perbankan dan DSN untuk aspek syariah (Karim, 2013: 258).

4. Monitoring Risiko

Berbagai aktivitas monitoring BSI tidak hanya meliputi manajemen bank Islam, tetapi juga melibatkan Dewan Pengawas Syariah. Secara sederhana, hal ini dapat digambarkan sebagai berikut (Karim, 2013: 259):
Tabel

Monitoring Risiko Pada Perbankan Syariah

\begin{tabular}{|c|c|c|c|}
\hline DPS & Frekuensi & Materi & Contoh \\
\hline $\begin{array}{c}\text { Board Level \& } \\
\text { Risk Manage- } \\
\text { ment } \\
\text { Committee }\end{array}$ & Tahunan & $\begin{array}{c}\text { Laporan Hasil } \\
\text { Pengawasan } \\
\text { Syariah }\end{array}$ & $\begin{array}{c}\text { Hasil Pengawasan } \\
\text { (narrative summary) }\end{array}$ \\
\hline $\begin{array}{c}\text { Middle Man- } \\
\text { agement }\end{array}$ & Triwulan & $\begin{array}{c}\text { Summary map } \\
\text { detail }\end{array}$ & $\begin{array}{c}\text { Kuadran opera- } \\
\text { tional risk } \\
\text { management plan }\end{array}$ \\
\hline $\begin{array}{c}\text { Day to Day } \\
\text { Operation }\end{array}$ & Bulanan & Detail & Frekuensi \\
\hline
\end{tabular}

Sumber:Li Falal Jurnal Studi Ekonomi dan Bisnis Islam

Dari itu, manajemen risiko yang efektif di BSI harus mendapat perhatian khusus. Namun, BSI memiliki banyak masalah yang kompleks yang perlu lebih dipahami. Secara khusus, risiko yang dihadapi BSI hampir dalam jumlah tak terbatas. Diperlukan solusi inovatif yang dibutuhkan dalam pengelolaan manajemen risiko agar dapat mestabilkan proses lembaga keuangan syariah.

\subsection{Implementasi Manajemen Risiko Pada BSI}

Manajemen risiko merupakan suatu pembuatan keputusan yang berkontribusi terhadap tercapainya tujuan perusahaan dengan penerapan baik di tingkat aktivitas individual dan dalam bidang fungsional (Henz and Berg, 20 I0: 79-95). Hal ini juga senada sebagaimana yang dikemukakan oleh Umam, (2013: 134), bahwa keberadaan Manajemen risiko sebagai unsur penting yang penerapannya sangat perlu diperhatikan, khususnya pada bank sebagai salah satu lembaga keuangan.

Proses implementasi manajemen risiko dapat meningkatkan shareholder value, memberikan gambaran kepada pengelola bank mengenai kemungkinan kerugian bank di masa mendatang, meningkatkan metode dan proses pengambilan keputusan yang sistematis yang didasarkan atas ketersediaan informasi, yang digunakan sebagai dasar pengukuran yang lebih akurat mengenai kinerja bank, serta menciptakan infrastruktur manajemen risiko yang kokoh dalam rangka meningkatkan daya saing bank (Rivai dan Arifin, 20 I3: 94I).

Bagi perbankan dapat meningkatkan share value, memberikan gambaran kepada pengelola bank mengenai kemungkinan kerugian bank di masa datang, meningkatkan metode dan proses pengambilan keputusan yang sistematis 
didasarkan atas ketersediaan informasi, digunakan sebagai dasar pengukuran yang lebih akurat mengenai kinerja bank, digunakan untuk menilai risiko yang melekat pada instrument atau kegiatan usaha bank yang relatif kompleks serta menciptakan infrastruktur manajemen risiko yang kokoh dalam rangka meningkatkan daya saing bank (Yulianti: I5I-165)

Praktik manajemen risiko di BSI dapat menggunakan berbagai alternatif penilaian profil risiko. Standar Basel II menggunakan beberapa altenatif pendekatan macam- macam risiko dalam menghitung kebutuhan modal yang sesuai dengan profil risiko bank. Melalui implementasi Basel II pula, Bank Indonesia diharapkan dapat meningkatkan aspek manajemen risiko agar bank semakin resisten terhadap perubahanperubahan yang terjadi baik di dalam negeri

Penerapan manajemen risiko di BSI wajib disesuaikan dengan tujuan, kebijakan usaha, ukuran, dan kompleksitas usaha serta kemampuan bank. Kompleksitas usaha adalah keragaman dalam jenis transaksi produk/jasa jaringan usaha. Sementara itu, kemampuan bank meliputi kemampuan keuangan, infrastruktur pendukung, dan kemampuan sumber daya insani (Rianto, 20I3:36).

Penerapan manajemen risiko paling kurang memuat: (I) Penerapan manajemen risiko secara umum; (2) Penerapan manajemen risiko untuk masing-masing risiko, yang mencakup 8 (delapan) risiko, yaitu risiko kredit, risiko pasar, risiko likuiditas, risiko operasional, risiko hukum, risiko strategis, risiko kepatuhan, dan risiko reputasi; (3) Penilaian profil risiko (lkatan Bankir Indonesia: 342).

Dalam Implementasinya, proses identifikasi, pengukuran, pemantauan dan pengendalian risiko memperhatikan halhal sebagai berikut:

Pertama, Identifikasi risiko dilaksanakan dengan melakukan analisis terhadap: (a) Karakteristik risiko yang melekat pada aktivitas fungsional; (b) Risiko dari produk dan kegiatan usaha.

Kedua, Pengukuran risiko dilaksanakan dengan melakukan: (a) Evaluasi secara berkala terhadap kesesuaian asumsi, sumebr data, dan prosedur yang digunakan untuk mengukur risiko; (b) Penyempurnaan terhadap siistem pengukuran risiko apabila terdapat perubahan kegiatan usaha, produk, transaksi dan faktor risiko yang bersifat material.

Ketiga, Pemantauan risiko dilaksanakan dengan melakukan: (a) Evaluasi terhadap eksposur risiko; (b) Penyempurnaan proses pelaporan apabila terdapat perubahan kegiatan usaha, produk, transaksi, fakto risiko, teknologi informasi dan sistem informasi manajemen risiko yang bersifat material.

Keempat, Pelaksanaan proses pengendalian risiko, digunakan untuk mengelola risiko tertentu yang dapat membahayakan keberlangsungan bank (Karim, 20I3: 260).

Sedangkan, Kualitas penerapan manajemen risiko meliputi:

Tata kelola risiko (risk governance). Tata kelola risiko (risk governance) mencakup pengawasan aktif (management oversight) Dewan Komisaris dan Direksi, serta risk appetite.

Kerangka manajemen risiko (risk management framework). Kerangka manajemen risiko (risk management framework) meliputi kecukupan kebijakan, prosedur, dan penetapan limit. 3

Kecukupan proses manajemen risiko.Proses manajemen risiko terdiri atas proses identifikasi, penilaian, pengendalian (mitigasi risiko), serta sistem informasi manajemen risiko.

Sistem pengendalian internal yang menyeluruh (Ikatan Bankir Indonesia: 347). Secara sederhana, uraian profil risiko dapat digambarkan melalui iustrasi berikut (Ikatan Bankir Indonesia: 349):

\section{KESIMPULAN}

Bank syariah Indonesia (BSI) akan selalu berhadapan dengan berbagai dengan berbagai jenis risiko dengan kompleksitas beragam dan melekat pada kegiatan usahanya. Risiko dalam konteks perbankan merupakan suatu kejadian potensial, baik dapat diperkirakan (anticipated) maupun yang tidak dapat diperkirakan (unanticipated) yang berdampak negatif terhadap pendapatan dan permodalan bank

Manajemen risiko pada BSI mempunyai karakter yang berbeda dengan bank konvensional, terutama karena adanya jenis-jenis risiko yang khas melekat hanya pada bank-bank yang beroperasi secara syariah. Dengan kata lain, perbedaan mendasar antara bank Islam dan bank konvensional bukan terletak bagaimana cara mengukur (how to measure), melainkan pada apa yang dinilai (what to measure)

Penerapan manajemen risiko pada BSI setidaknya memuat: Penerapan manajemen risiko secara umum; Penerapan manajemen risiko untuk masing-masing risiko, mencakup 8 risiko, yaitu risiko kredit, risiko pasar, risiko likuiditas, risiko operasional, risiko hukum, risiko strategis, risiko kepatuhan, dan risiko reputasi. Penilaian profil risiko. Kualitas penerapan manajemen risiko meliputi: Tata kelola risiko Kerangka manajemen risiko Kecukupan proses manajemen risiko dan Sistem pengendalian internal yang menyeluruh. 


\section{DAFTAR PUSTAKA}

Arifin, Zainul. Dasar-dasar Manajemen Bank Syariah. (Jakarta:Azkia Publisher, 2009)

Emira, dkk. "Comparative Analysis Of Risk Management In Conventional And Islamic Bank", Journal International Buseness Research,Vol. 6. No. 5. (2013).

Henz and Berg. "Risk Management, Procedure, Methods, And Experiences," Journal RT \& A, Vol. I, No. 2 (20I0).

Ikatan Bankir Indonesia. Memahami Bisnis Syariah. (Jakarta: Gramedia Pustaka, 20I4).

Irham Fahmi. Manajemen resiko. (Bandung:Alfabeta, 20I0).

Karim, Adiwarman. Bank Islam:Analisis Fiqh dan Keuangan. (Jakarta: Raja Grafindo Persada, 20 I3).

Khan and Ahmed."Risk Management: An Analysis of Issues in Islamic Financial Industry," Occasional Paper, No. 5. Jeddah: Islamic Development Bank (IRTI) (200I).

Muhammad. Manajemen Bank Syariah. (Yogyakarta: STIM YKPN, 20II).
Rianto, Rustam Bambang. Manajemen Resiko Perbankan Syariah di Indonesia. (Jakarta: Salemba Empat, 20I3).

Romdhoni, Abdul Haris. "Analisis Manajemen Pembiayaan Mudhorobah Di Bank Syariah Surakarta." Yogyakarta: Tesis UIN Sunan Kalijaga (20I2).

Saputra,Anda.Manajemen Resiko Pembiayaan Mudhorobah. Yogyakarta:Tesis UIN Sunan Kalijaga, (2012)

Suryani. "Sistem Perbankan Islam di Indonesia: Sejarah dan Prospek Pengembangan.” Muqtasid: Jurnal Ekonomi dan Perbankan Syariah,Vol. 3, No.I (2012)

Umam, Khoirul. Manajemen Perbankan Syariah, (Bandung: Pustaka Setia, 2013).

Veitzal, Rivai dan Arviyan Arifin. Islamic Banking: Sebuah Teori, Konsep dan Aplikasi, (Jakarta: Bumi Aksara, 20 I0).

Yulianti, Rahmani. “Manajemen Resiko Perbankan Syariah" Jurnal La Riba Vol. 3, No. 2. (2009). 